\title{
A Pilot Site Approach for Built Heritage Diagnosis: The Preservation and Conservation of Egongot Ethnic Minority
}

\author{
John Cedierick P. Abarca, Ar. Jocelyn A. Rivera-Lutap*, Raydett Kelly C. Ronquillo, \\ John Dence S. Suizo
}

College of Architecture, Design, and the Built Environment, Polytechnic University of the Philippines, Philippines

Received September 29, 2021; Revised January 7, 2022; Accepted February 8, 2022

\section{Cite This Paper in the following Citation Styles}

(a): [1] John Cedierick P. Abarca, Ar. Jocelyn A. Rivera-Lutap, Raydett Kelly C. Ronquillo, John Dence S. Suizo , "A Pilot Site Approach for Built Heritage Diagnosis: The Preservation and Conservation of Egongot Ethnic Minority," Civil Engineering and Architecture, Vol. 10, No. 2, pp. 490-500, 2022. DOI: 10.13189/cea.2022.100209.

(b): John Cedierick P. Abarca, Ar. Jocelyn A. Rivera-Lutap, Raydett Kelly C. Ronquillo, John Dence S. Suizo (2022). A Pilot Site Approach for Built Heritage Diagnosis: The Preservation and Conservation of Egongot Ethnic Minority. Civil Engineering and Architecture, 10(2), 490-500. DOI: 10.13189/cea.2022.100209.

Copyright $\mathrm{C} 2022$ by authors, all rights reserved. Authors agree that this article remains permanently open access under the terms of the Creative Commons Attribution License 4.0 International License Abstract

\begin{abstract}
In the Philippines, some ethnic minority-built heritages are frequently misunderstood, and most are not given adequate attention in assessing their cultural significance. Consequently, people often lack adequate knowledge in the proper conservation and preservation of remaining cultural treasures. This may further result in the degradation, if not the oblivion, of key Filipino cultural values. It is with the use of the Pilot site procedure that we approached the architectural practice of Heritage conservation as we diagnosed the traditional dwellings of Egongot people of Aurora province in giving light to their traditional architecture as a vital built heritage in the country. The pilot site approach made use of historical documentation and surveys as well as present architectural condition assessment through observation. The first phase of the pilot site is the historic data collection which provided the traditional construction process and the use of vernacular materials. The second phase which is the architectural assessment provided observational information of its current state after the intervention of conservation treatment. The last phase of the pilot site approach which is the diagnosis of conservation treatment, is the consequent analysis of both past and present. These two factors are utilized to formulate a comparative analysis of 'how it used to be' and 'how its current state is'. The results showed various manipulations of construction methods and integration of modern building materials that threaten both the identity and structural integrity of the
\end{abstract}

built heritage. As a result, appropriate preservation and maintenance guidelines are formulated to better appreciate the heritage architecture's historic and cultural value.

Keywords Built Heritage, Pilot Site Approach, Historical Documentation, Architectural Condition Assessment, Conservation Treatment, Preservation

\section{Introduction}

\subsection{Background}

The study on the Indigenous People (IP) is a multi-disciplinary task from the perspectives of the anthropologists, sociologists, professionals of the built environment, and historians to be able to promote their contribution and experience and to ensure equal recognition of their influence of what we are today. The Philippines, a country in South East Asia, has an estimated 17 million IPs with 110 ethnolinguistic groups as reflected in Figure 1. They are distributed in the 2 major islands of the country where $33 \%$ are in Luzon, $61 \%$ are in Mindanao, with some small groups in the islands of Visayas. The Philippine Constitution has acknowledged and celebrated the diversity of the country and is recognized and protected 
by Republic Act 8371, also known as the "Indigenous Peoples Rights Act” 1997, IPRA.

Ethnographic studies have recorded historical data of significant precedence of native Filipinos. The ethnic tribes of the Cordillera Region of Luzon who were referred to as "savages," "treacherous murderers," and "cannibals" because of their horrifying tradition of headhunting is commonly associated with the Igorot people. Although this ethnic group is composed of many other ethnic minorities which traditionally practice taking human heads, neither the Igorot people nor other ethnic groups in the Cordillera mountains are as wild as the people who emerged from the Sierra Madre range with the Caraballo Sur. These groups of indigenous people are wild and inhabitants of forests from which people living adjacent to them on the north, west, and south have referred to them as "Italon," "Ibilao,"
"Ilongot," or "Ilūngūt." [1]. However, the study will show the sophistication of the IPs through the documentation of their architecture.

According to Barrows [1], Ilongot homes have two varieties, one that is built as low wretch hovels that are about two or three feet from the ground, with grass for roof and walls of bark, and one that is set high above the ground, reaching up to twelve feet, situated on numerous poles for the foundation. The 12 feet house is more frequently used by Ilongots. The floor of the house is formed from meticulously set strips of palm brava, the lintels, the doorposts, and other exposed surfaces of the structure are curiously carved. Moreover, the interior is built with a large single room. This is because not one, but several families occupy the room with a hearth in each four corners.

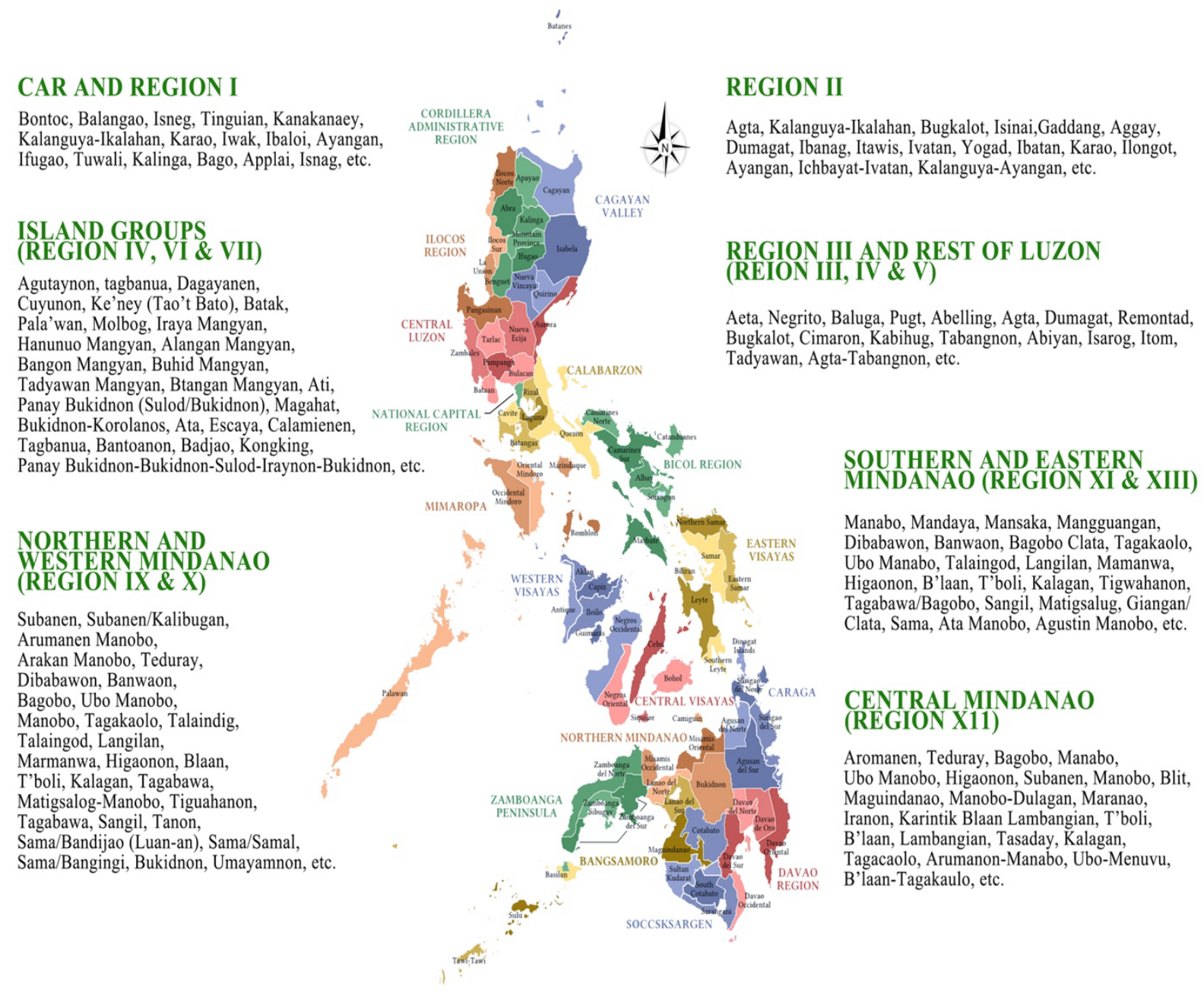

Figure 1. The Philippine Ethnographic Map (Source: Dapar, 2020) 


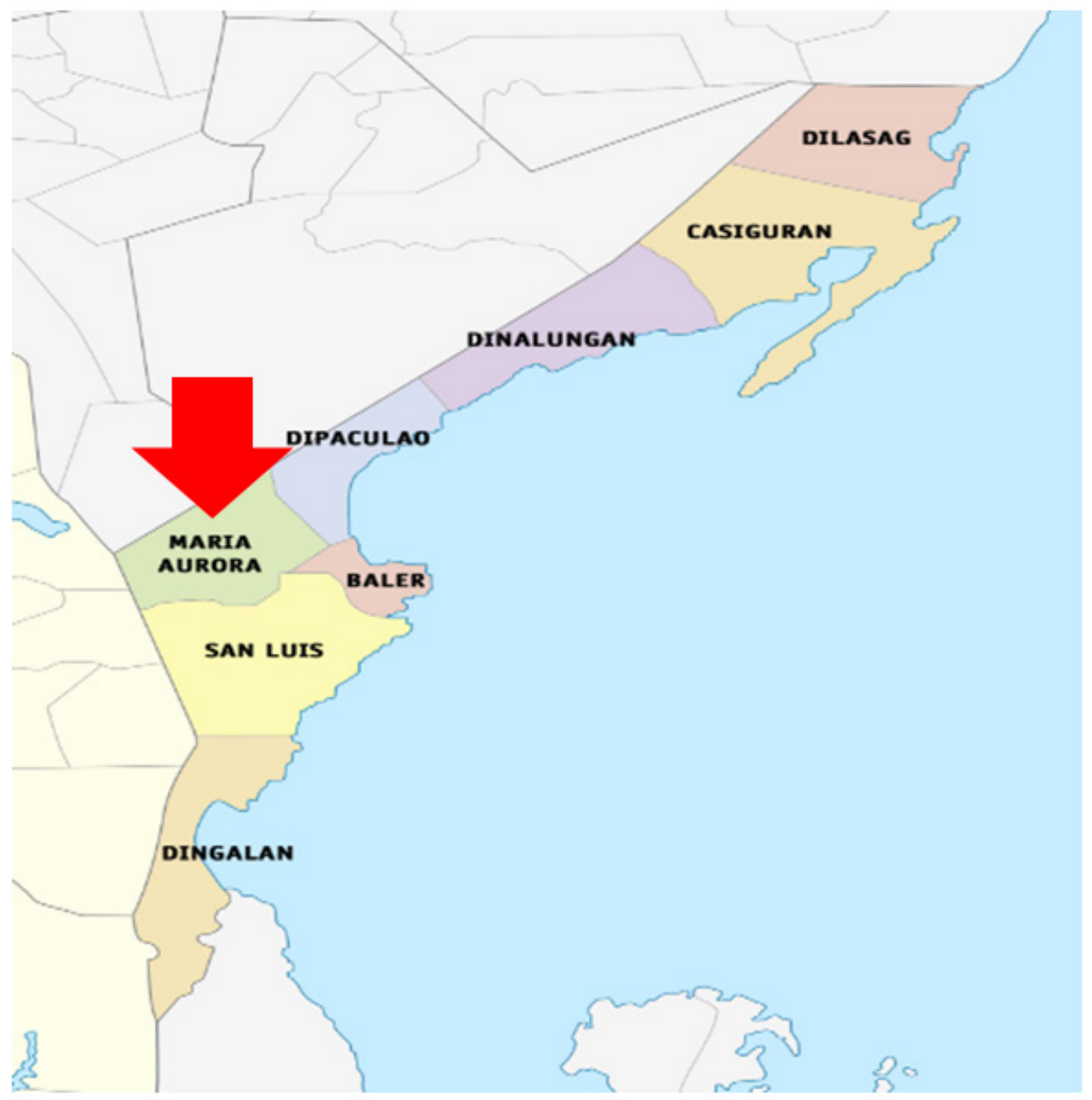

Figure 2. Aurora Map (Source: Balingit, 2012)

The nomadic lifestyle of Ilongots paved the way for the spread of its people and resulted in the variations of names for every tribal group [1]. Although there is no existing documented proof that Ilongots have ever resided in Aurora, their nomadic lifestyle may prove to be of significance for another tribal group that is not mentioned in any ethnographic studies, the Egongots. Shown in figure 2 is the Map of Aurora province wherein it is situated at Brgy. Bayanihan, Maria Aurora, Aurora adjacent to the southern borders of Nueva Vizcaya. The Egongots are an undocumented community of Ilongots that reflect a similar lifestyle and tradition of headhunting and architecture from its relative tribes.

\subsection{Problem Statement}

The inevitable advancements brought by technology throughout history caused the gradual degradation of our diverse cultural sites of historic ethnic minorities in the Philippines, one of which is the traditional houses of Egongots.

The lack of legal and sufficient information in the practice of conservation and preservation of remaining built heritage may lead to the degradation and even the oblivion of significant cultural values.

\subsection{Goal and Objectives}

The goal of this study is to provide an appropriate diagnosis to the remaining Egongot traditional dwelling giving light and attention to the underrated historic ethnic minority group and sites in the country.

The need to study the heritage specifically the indigenous people will guarantee equal recognition of their place in the history of our nation and the world's civilization. This study aims to analyze the current material 
and structural aspects of the built heritage to provide sufficient information for diagnosis and the appropriate preservation strategies.

This research aims to document and provide a detailed explanation of the existing structures.

This research seeks to understand the value of historic cultural and architectural knowledge of the Egongot tribe for an authentic interpretation of shared information.

\subsection{Scope and Limitations}

The research encompasses the analysis and diagnosis of the conservation and preservation of the built heritage which is the traditional Egongot dwellings. This initiative should restore the ethnic minority group's traditional dwellings to their original form and value without compromising their authenticity. Through prudent inquiry and a scientific approach, 3 of the monuments must be evaluated and appreciated particularly the two dwelling structures namely: Kamage and Abong houses, and the communal structure Sepzo, to enable the recapturing of the original fabric and character of the cultural structure. This can only be done by formulating an assessment framework that would provide the researchers with sufficient information for the appropriate analysis and diagnosis of the existing built heritage. This would result in better and appropriate restoration techniques and strategies for the preservation of such a valuable historic structure.

\subsection{Significance of the Study}

The restoration of ethnic minority groups of Egongots' built heritage located in Aurora demonstrates that heritage preservation as markers of national identity does not have to be restricted to religious structures or to any time period, colonial or not. It also disproves the notion that conserved buildings are of no practical value, arguing instead that their restoration should always aim to preserve their integrity as part of architectural value. The authentic cultural intent of the indigenous builders should be of priority over any design intervention.

\section{Materials and Methods}

\subsection{Method of Approach}

The pilot site approach is a learning process that gradually combines results from various research contributions to support the conservation project formulation. The historical survey and documentation, architectural condition evaluation, and conservation treatment diagnosis are the three primary phases of the pilot site activity for this research. The pilot site's key operations are mostly concentrated in the first two phases, while the third represents the comparative analysis and interrelationships of factors with regards to the resultant diagnosis [2]. Figure 3 illustrates the phases, objectives, and expected results of the pilot site approach.

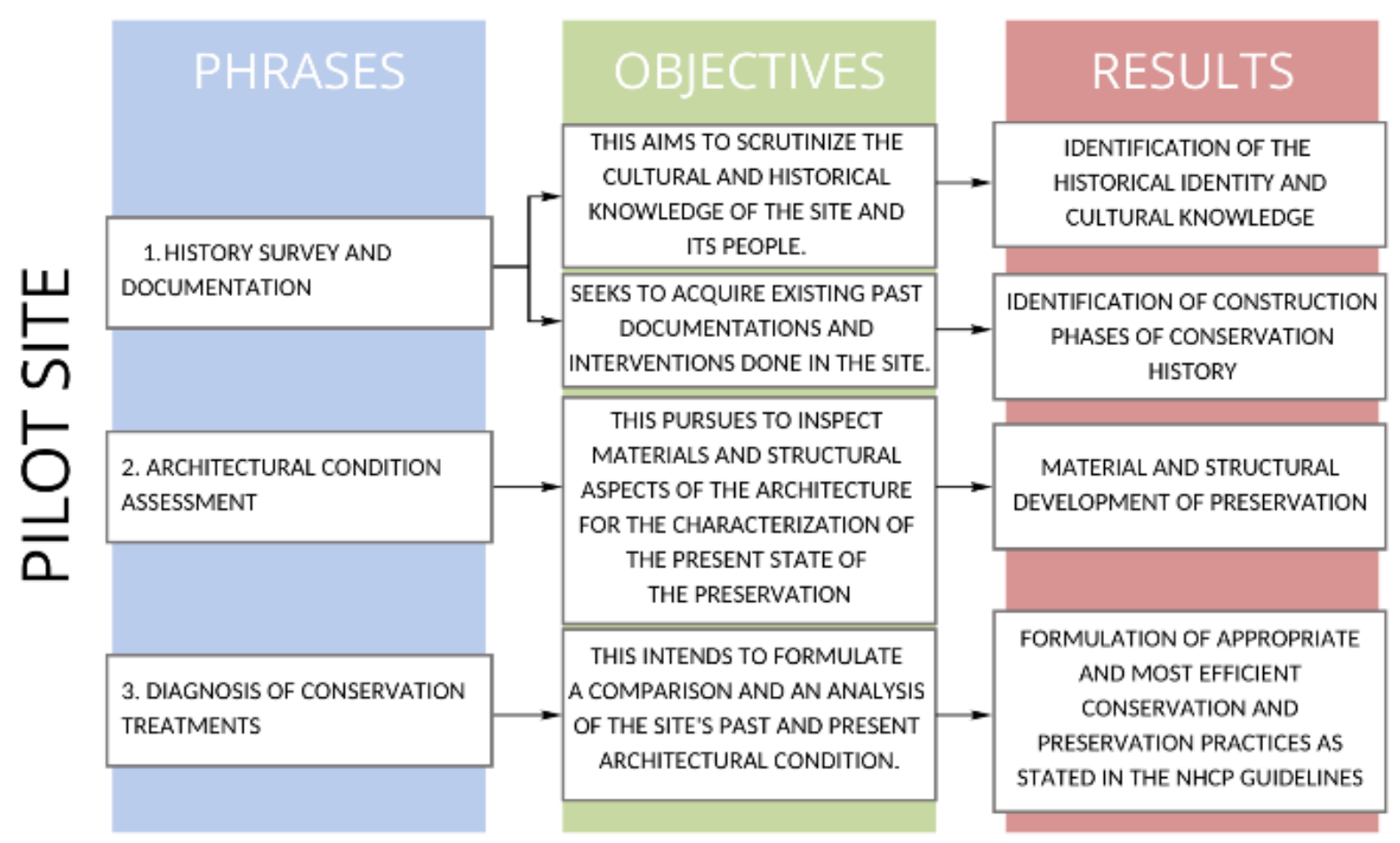

Figure 3. The Phases, Objectives, and Results of the Pilot Site Approach (Source: Gullota, 2019) 


\subsubsection{Historical Survey and Documentation}

During phase 1, all historical and past information regarding the site are gathered and analyzed. These collected data include archeological findings and historical documents that describe the original identity of the built heritage as described by its people. One way to gather reliable data is through the parallelism of the statement of the interviewee and historical data. A survey is conducted to gather sufficient information to further strengthen the existing knowledge about the built heritage. Data collection includes conducting conversations with village elders and gathering historical or written data on weathering, construction procedures, and material sourcing.

\subsubsection{Architectural Condition Assessment}

Phase 2 includes the analysis of structural identity and material characterization of the built heritage. On the paper of Onay [7], a framework was developed for examining subsisting structures to be able to establish the most relevant objective and method of use. As a result, the method's emphasis is to comprehend the architectural and spatial potentials contained within the structure and its elements. Onay [7] emphasizes that the city or landscape in which any architectural structure is defined is its context, whereas the context of any interior is the structure in which it is enclosed. Hence, a framework was made up of two main steps: exploring the structure in its entirety and examining its core.

\subsubsection{Diagnosis of Conservation Treatments}

In the last phase, the researchers made use of the preservation and conservation diagnosis of built heritage structures which were emphasized in phase 2 of Architect Ignacio's [4] study on the challenges in preserving the heritage houses of Batanes, Philippines. Phase two focuses on the diagnosis and formulating and establishing guidelines on preservation and conservation practices. The process of phase 3 includes the assessment and comparative analysis of the past historical documentation to that of the existing architectural conditions as building preservation was established. Establishing alternative construction technologies and materials that promote the utilization of existing architectural know-how in the region without jeopardizing the forms of existing heritage houses is also part of this. As a result, criteria for safeguarding heritage structures would be developed.

\section{Results}

\subsection{Historical Survey and Documentation}

To address the culturally unique elements of the Egongot tribal village, the researchers conducted an interview to collect in-depth information about it. Mr. Romeo Cawad, the Chieftain and the Chairman of
Egongots in Aurora, who is a direct descendant of the Egongots is the interviewee. He states that the Egongot tribe in Barangay Bayanihan was the first inhabitants of the town of Maria Aurora. They were known for their intense aggressiveness as a tribe of headhunters and relative cultural simplicity. They usually reside along the river to meet their basic needs like washing, taking a bath, and defecating.

According to Cawad, there are many Abong and Kamage houses around a Sepzo erected in the site which were built from materials that wood borers cannot infest easily. Bamboo, Rattan, Narra, Haligi, Tudok, Buangsina, Biyaw and Kabunegro are commonly used for the walls while hardwoods like Mulawin, Guijo, Rattan, Kamagong, Tamoyan, Etek, Tagep, Kaliot, Masanoza, Balayong, Amugis, Kata'e, Malabayabas, Dezek, Sopa, Tangilingbato, Dungon, Mapged, Saplungan, and Abuk are used for the columns. Cogon grass, Anahaw leaves, and leaves of Biyaw are used for the roof which can be found in the mountain ranges of Sierra Madre.

He also quoted that the Egongots have a unique way of constructing their ceiling which is called Seprat which alternates the Narra wood, Rattan, and the cogon grass. Figure 4 depicts a Tangkolok or Eteng which is a wood carving that is inspired by the beak of a Rufous hornbill, locally known as Kalaw bird, on the apex of the roof. Not all houses are built with Tangkolok, it can only be seen on the houses of the elite warriors and brave headhunters. It is a representation of the tribe's pride and valor.

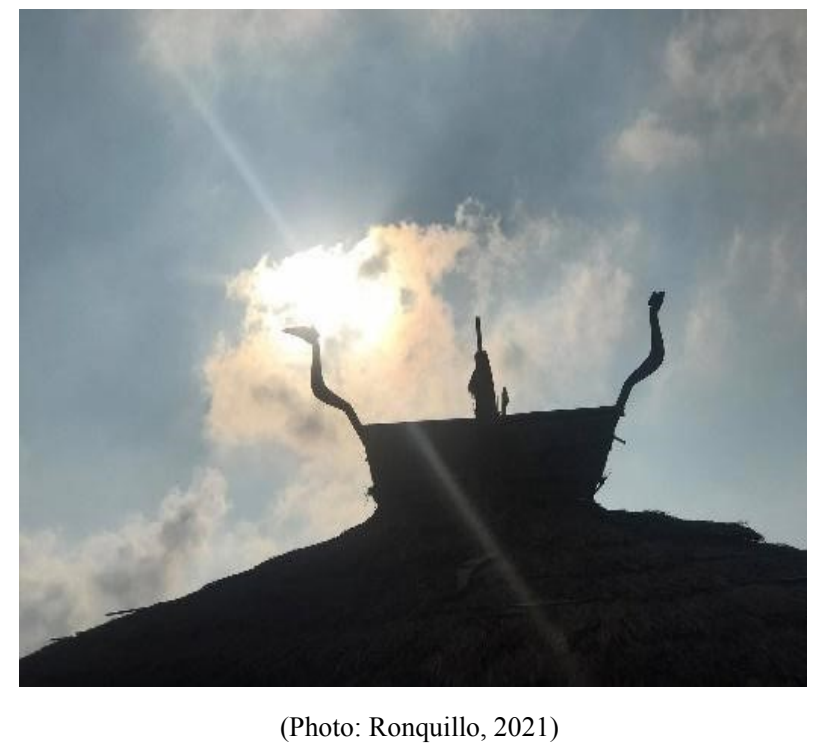

Figure 4. The Tangkolok or Eteng

Cawad also states that the Egongots used a unique kind of wood joinery on every corner of the house where they creatively weaved the Rattan skin around the materials. Figures 5 and 6 showcase the different wood joinery techniques used by the Egongots. The weaving on the upper part of the house or in the roof of the house is generally termed as bin'gad o binen'gad while the weaving on the lower part or in the walls is called kenindo. 

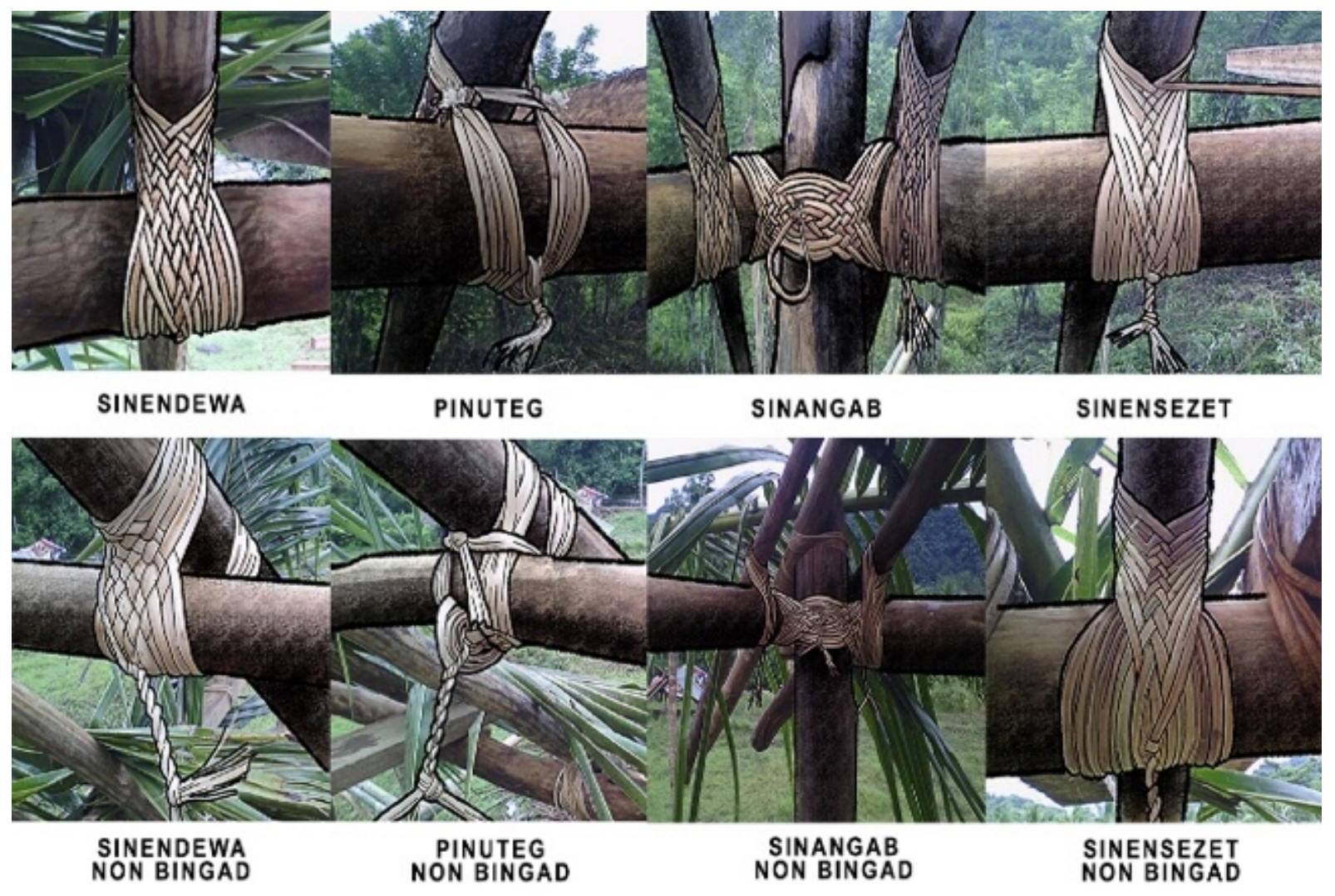

Figure 5. Different Types of Wood Joinery Using bin'gad o binen'gad (Source: Amatorio, 2017,)

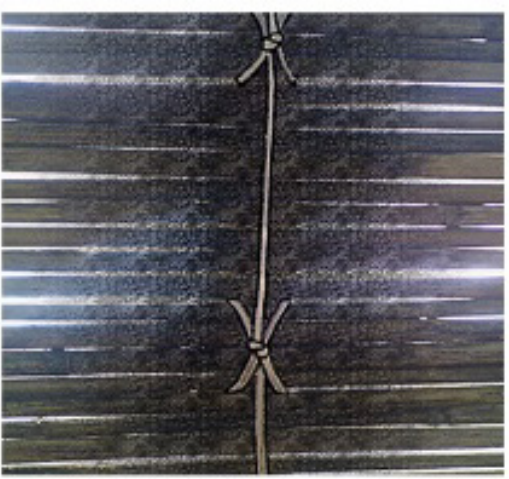

BINAONG

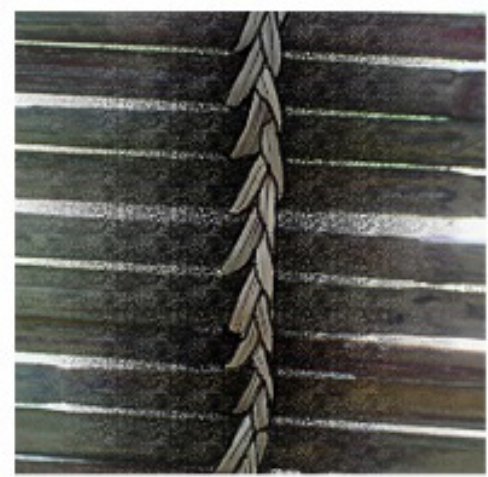

SINAGINIT

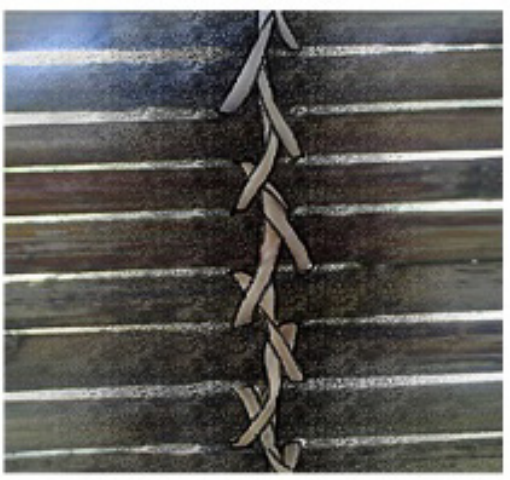

SINEKO

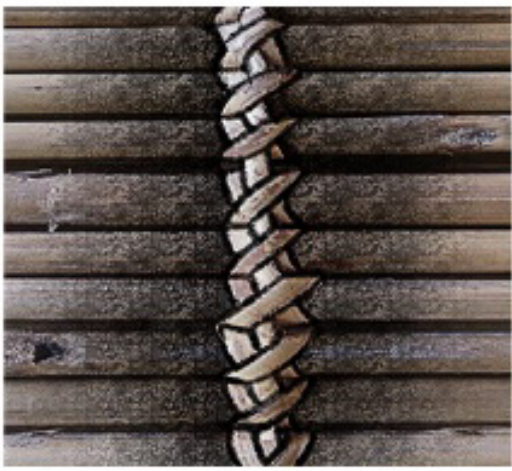

SINAZAK

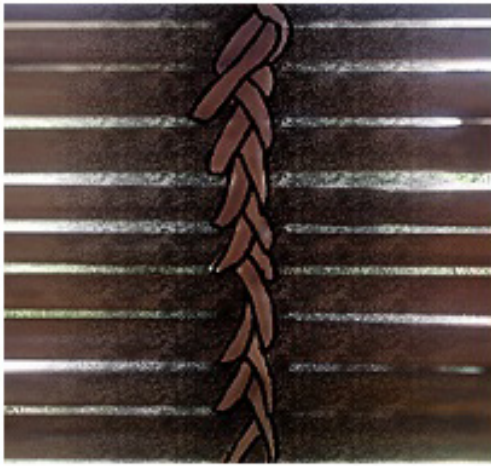

MONOGAN

(Source: Amatorio, 2017)

Figure 6. Different Types of Wood Joinery kenindo 
He further mentioned that the interior of the house is built with a large single room with no room dividers to accommodate more than one family inside. All their house equipment is inside, for example, their stove is in the middle of the house. The main reason for building such unique homes is the joint work of men, women, and children in the village. The males are the major constructors while the women help in collecting cogon grass for the roof and cooking food for the tired workers. The children also help by following the command of the elders.

The information stated by Cawad was also affirmed in the booklet of Mr. Ronnie Amatorio [5] which is entitled, Egongot Tribe Indigenous Knowledge Systems and Practices in Aurora Province.

At the end of the interview, Cawad acknowledged that the old Egongot village changed a lot from its present state. The once lively village filled with simplicity and camaraderie is now gone. He claims that he cannot blame his people for wanting to live their lives, but he still wishes for the preservation and restoration of the three remaining structures so that their culture and identity won't fade.

\subsection{Architectural Condition Assessment}

\subsubsection{Structural and Material Conditions}

On November 11, 2020, typhoon Ulysses whipped destructive winds and dumped heavy rainfall over the province of Aurora. This resulted in the destruction of the buildings including the tribal village of the Egongot. The Abong, Kamage, and the Sepzo are the three structures that remain standing but are greatly damaged.

\section{Abong House}

Figure 7 shows the bigger type of Egongot house which is called the Abong with dimensions 4 by 3 meters. It is elevated 1.3 meters above the dampness of the ground and to keep away from the snakes and the vermin. Figure 8 shows the interior of the Abong house that depicts the height of the floor to the apex of the steep roof is 3 meters that provide a dense shade from the sun during summer and sheds the torrential downpour of rains. It has a balcony unlike the other house with dimensions 2.6 by .9 meters and a .8 by .8 meters' square window on the right side of the house. The interior is plain with no rooms and dividers.

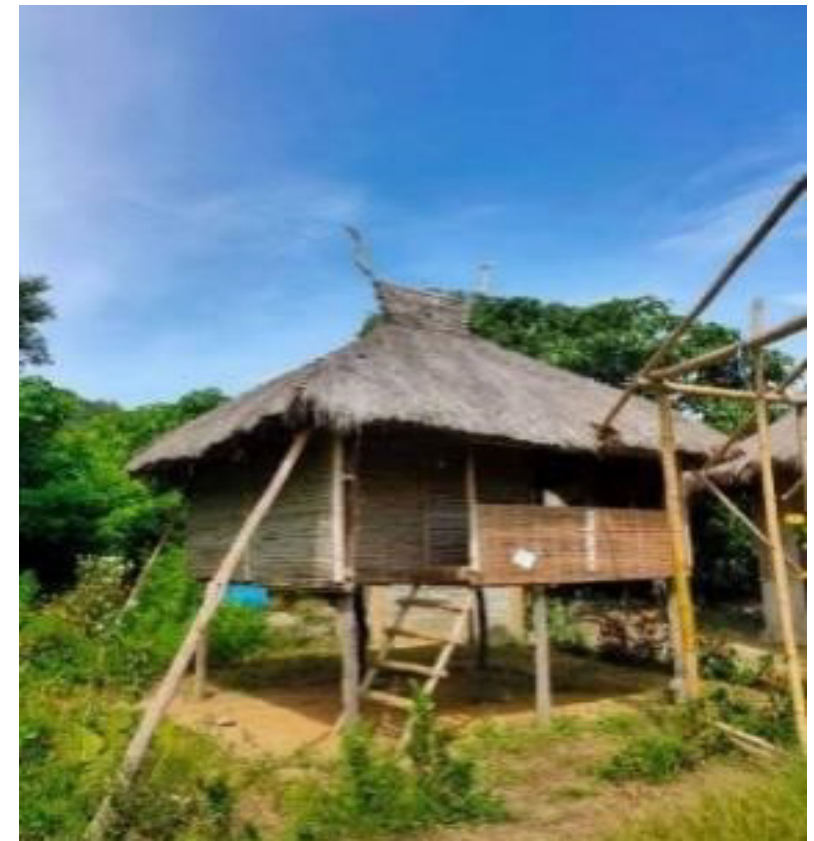

(Photo by: Ronquillo, 2021)

Figure 7. Present condition of the Abong House

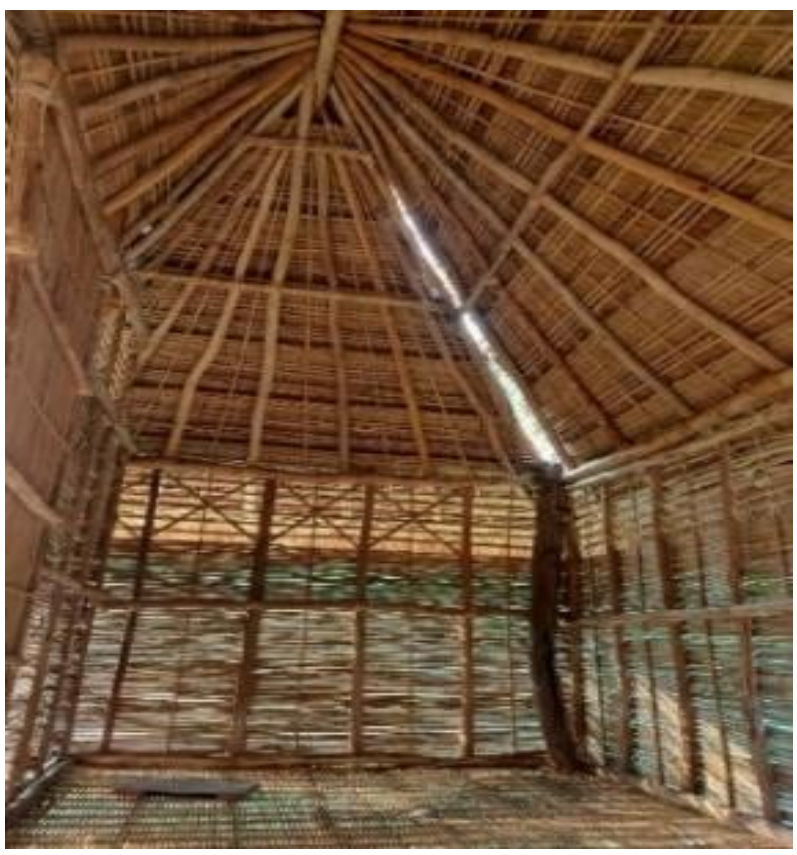

(Photo by Ronquillo, 2021)

Figure 8. Interior of the Abong House 


\section{Kamage House}

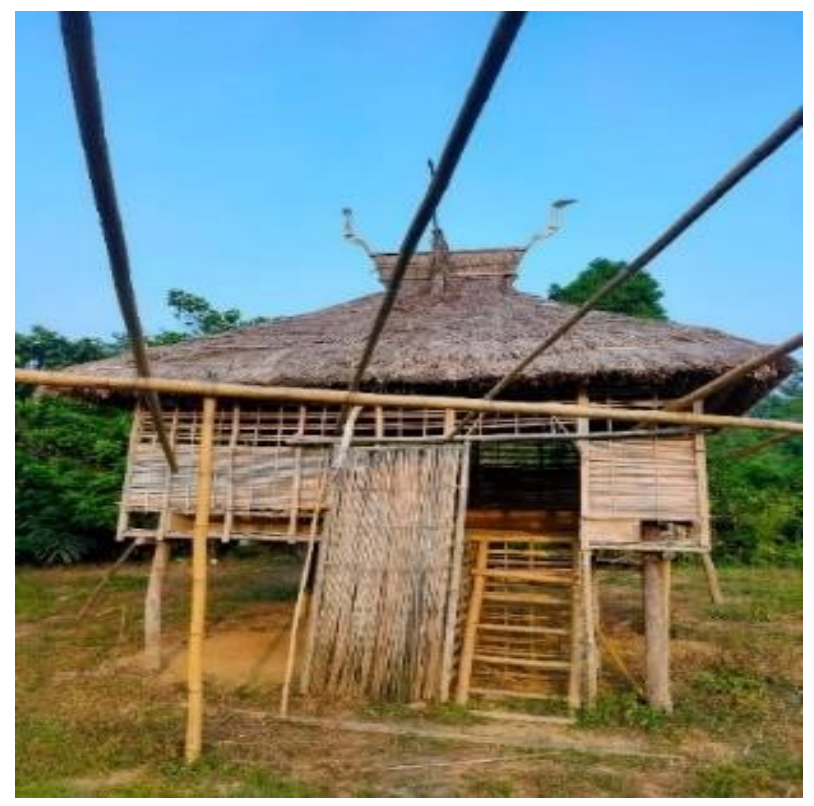

(Photo: Ronquillo, 2021)

Figure 9. Present condition of the Kamage House

Figure 9 shows the smaller type of Egongot house which is called the Kamage with dimensions 3.5 by 3 meters. Figure 10 depicts the interior of the Kamage house which shows that it is 3 meters from floor to the apex of the roof.
It is also elevated 1.3 meters above the ground. It has no balcony and windows but there are small openings on the walls for better air circulation. The interior is plain with no rooms and dividers, but it has chairs surrounding the inside of the house.

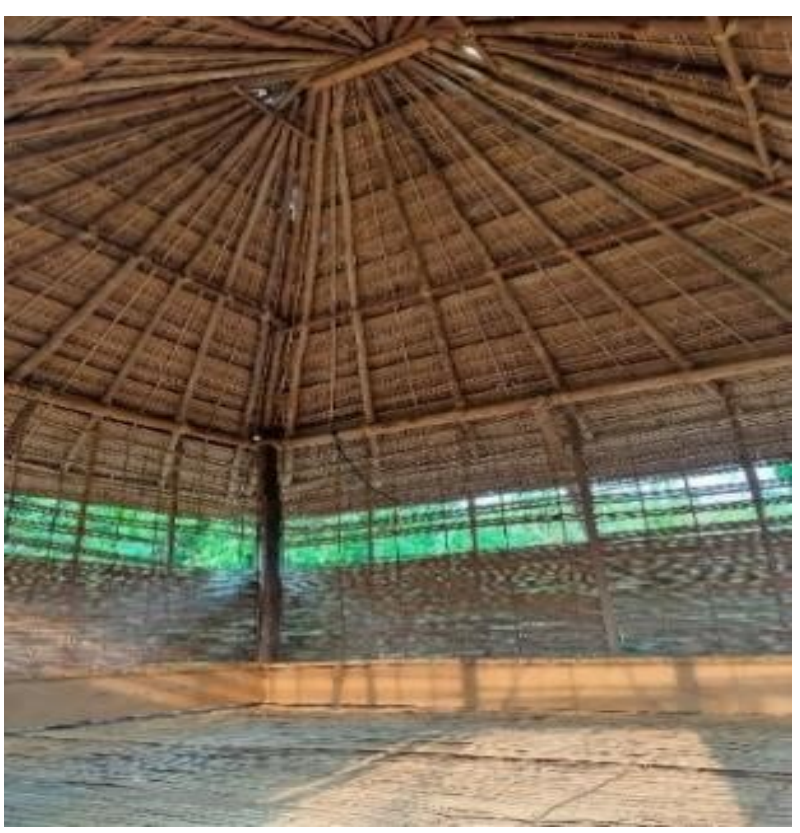

(Photo by Ronquillo, 2021)

Figure 10. Interior of the Kamage House

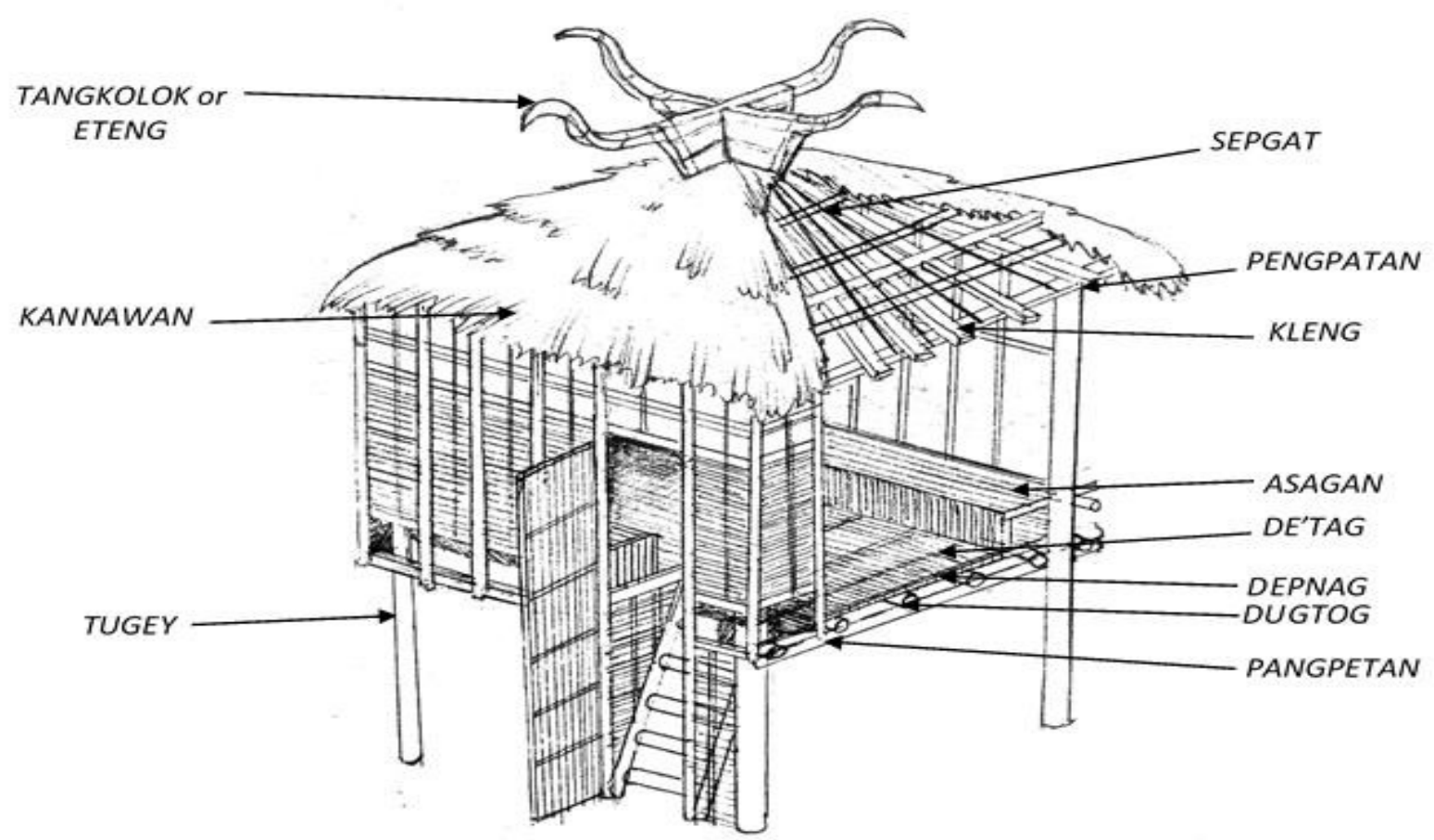

Figure 11. Anatomy of the Kamage House with Vernacular Terms (Drawn by Abarca, 2021) 
Figure 9 the exterior of Kamage House and Figure 10 its interior exemplifies the vernacular terms that are traditionally used by the Egongot tribe. The Egongot tribe speaks the Bugkalot language. They have numerous construction vernacular terms as shown in Figure 11. Starting from the top of the house, the wooden carving on the top of the roof that is inspired by the Kalaw bird is called the Tangkolok or Eteng. The Kannawan is the roof or upper covering composed of dried Cogon leaves. The Sepgat is the slope structural member in the middle of the Kleng and Kannawan. It is where the Kannawan is attached while the Kleng is the rafter that supports the roof. The Pengpatan is a horizontal structural member or a beam that is made up of hardwood which supports a load transversely while the Tugey is a vertical structural member or a column that is made up of hardwood that supports the load from the ceiling to the foundation. The Pengpetan is the main element in a framed floor supporting the other floorboards. The Dugtog is a piece of wood laid inversely with the Pengpetan. The Degnag is small wood support between the Duptog and the De'tag is the main flooring of the room upon which one seat is made up of Rattan. There is a particular feature on a Kamage house called the Asagan which is a built-in wooden chair around the interior of the house [4].

\section{Sepzo}

The communal hall of the Egongot is called the Sepzo. Here is where the people in the community gather for group activities, public information, making a feast together, and heating their bodies during the cold months.

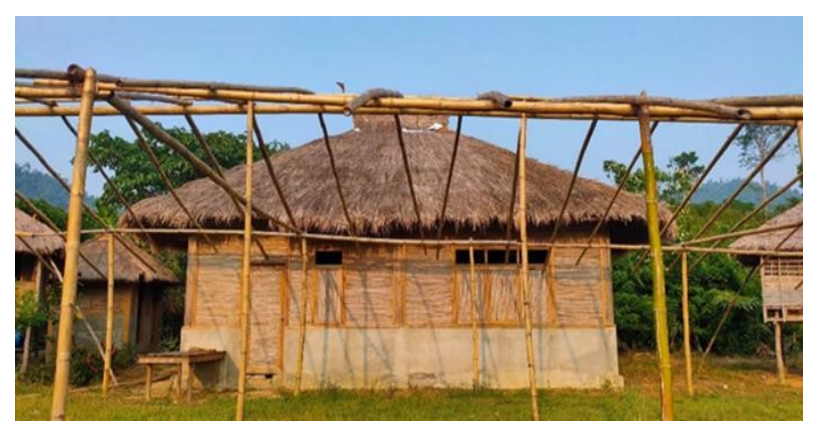

(Photo: Ronquillo, 2021)

Figure 12. Present Condition of the Sepzo

The Sepzo which is reflected in Figure 12 is 9.3 meters long and 6.2 meters wide. The height of the hall is 3.7 meters from floor to ceiling. It has two types of windows, single casement and triple casement windows with dimensions 2.1 meters by 1.3 meters. The interior is plain and an open space with no rooms and dividers.

The current Sepzo is built by fusing modern and traditional materials together. Figure 13 shows the present condition of Sepzo. Concrete cement is used on the interior flooring and on the lower part of the wall. Nails and screws are currently present in joining the woods instead of only weaving them together like the traditional way.

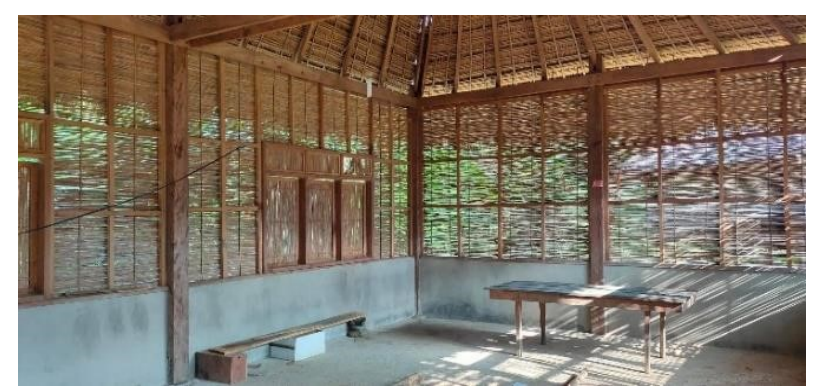

(Photo: Ronquillo, 2021)

Figure 13. The Sepzo Interior

\subsection{Diagnosis of Conservation Treatments}

Conservation technique requires a thorough grasp of structural and material properties. The information on the structure in its original and earlier states, the techniques employed in its construction, the modifications, and their effects, the phenomena that have occurred, and lastly, its current state are all necessary. Before deciding on structural intervention, it is critical to first discover the sources of deterioration and decay, and then assess the structure's level of safety.

The diagnosis of the current state of the Egabong Tribal Village is derived from the inspection and images taken on the site. After being hit by several typhoons and other natural calamities, the condition of the building materials has evident damages. The remaining structures have holes on the floor, on the roof, and on the walls. The posts and roof braces are already infested by wood borers. Some of the Tangkoloks have been snapped from its base. The area around the village is now filled with tall grasses.

\subsubsection{Material Analysis and Treatment}

The introduction of new materials may affect the quality of performance of the existing materials. Aside from its effects on the cultural identity it can also change and make an impact structurally. It is difficult to source the old wood materials used because most of them are not now widely available and are now protected due to deforestation. After a long time of being exposed to insects and diseases, most of the woods that are used in the assembly of the panels, floors, and roofs of the structures are now infected by wood borers. This is due to the use of softwoods. The original types of woods used in construction may have to be returned to avoid wood sickness.

\subsubsection{Safety Evaluation}

Conservation and reinforcing measures should be based on a safety assessment and understanding the structure's significance. During the rainy season, there are times where floods can reach the village because it is situated near the river. The elevated houses are not greatly affected 
but extreme precautions are still needed. The surrounding area of the village is now filled with tall grasses because there are no maintenance workers.

\subsection{Preservation and Maintenance}

The following preservation and maintenance recommendations are based on the data gathered from phases 1 and 2 as a response to the diagnosis of the architectural heritage. First, the data gathered from the historical survey and documentation phase showed numerous opportunities that could be reintegrated into architecture. One of which is the reintegration of traditional rattan weaving as a wood joinery method to replace nails and screws that would potentially revitalize its cultural identity. Furthermore, landscape maintenance should be practiced to lessen environmental factors affecting the structure. Also, it would be beneficial for the indigenous people and the national culture to propose a Municipal Ordinance to declare Egongot traditional houses as a cultural treasure and provide incentive packages, subsidies and set standards and a governing body that would spearhead the preservation and conservation initiative for the site that is tasked to perform all stated maintenance practices [4]. For the architectural condition assessment phase, it showed several structural and material implications upon evaluation. This includes the floor, roof, and wall holes that shall be fixed using indigenous materials such as Bamboo, Cogon grass, etc., through vernacular building methods. The revitalization of the structure through replacing softwood with traditional wood such as Narra, Kamagong, Bamboo, Malabayabas, etc., to be used to avoid wood sickness caused by wood borers. Additionally, replacing concrete walls and flooring of Sepzo should be done using vernacular hardwood materials such as Bamboo, Narra, and Mulawin; with the integration of Rattan wood joinery which was traditionally used.

\section{Conclusions}

Researches have consistently shown how the Indigenous People worked with the environment and have also adapted to nature. Their knowledge and expertise are imperative and critical on how we connect ourselves from the past to foresee the future.

The model conservation area is an effective way to address the innate challenge of preserving building heritage. In the case of the remaining Egongot ethnic built heritage, it demonstrated historical survey and documentation and existing architectural condition assessment as a methodology used to gain an accurate understanding of the site. The built heritage was historically and architecturally analyzed through contextual surveying and observational assessment respectively.

The historical data documentation procedure was critical in assessing the traditional materials and methods of building historical Egongot monuments such as the Abong house, Kamage house, and Sepzo. Information was derived primarily through a comprehensive interview with a reliable respondent such as the current chieftain of the Egongot ethnic group. This provided the researchers a significant foundation for better understanding of the forlorn house-building practice of the Egongots. This includes the use of vernacular materials derived from the environment such as Narra, Tudok, Bamboo, Malabayabas, Dezek, Cogon grass, Anahaw, etc., as well as the traditional way of wood joinery that utilizes Rattan strips.

The architectural condition assessment provided observational data that is vital in understanding the effects of recorded architectural interventions. The researchers conducted field research to observe and gather qualitative data that are present on the site. This provided information regarding the present condition of the built heritage as well as the material specifications that are presently observable. This includes the dimensions of the structures as well as the observable building materials used in the latest conservation treatment such as concrete, nails, screws, plywood, etc.

The information gathered allowed the researchers to formulate a comparative analysis of the past and the present. This comparison made it possible for the researchers to have a stronger comprehension of the significant effects of the conservation and preservation treatments. As a result, the final phase of the approach was able to establish a diagnosis of the existing built heritage. Thorough historical, present material and structural observation showed significant changes and technological implications in the Egongot traditional houses. The conservation intervention affected the ingenuity of materials used and its structural integrity is also observably influenced. As a result, better preservation and maintenance procedures were formulated to aid for existing damages. It is critical to follow particular procedures in this planned process that will finally lead to the protection of the cultural heritage asset [6] with the penultimate purpose of providing equal representation for the IPs.

\section{Acknowledgments}

The Researchers would like to express their sincere gratitude that is hereby extended to the following who never ceased in helping until this paper is successfully made:

Mr. Romeo Cawad, the current chieftain of the Egongot ethnic group for actively participating in the interview session in sharing his experiences and knowledge regarding their tribal culture and history.

DALUHAY, for the organization's genuine support and participation in providing additional knowledge for the research. 
To family and friends of the researchers, for their financial and moral support to the proponents.

Above all, utmost appreciation to the Almighty God for the divine intervention in this academic endeavor.

\section{REFERENCES}

[1] David B., "The Negrito and Allied Types in the Philippines and The Ilongot or Ibilao of Luzon", Gutenberg Popular Science Monthly, https://www.gutenberg.org/files/28577/28577-h/28577-h.h tm. (accessed July 7, 2021)

[2] David D., "Indigenous Peoples in the Philippines: A Country Case Study", RNIP Regional Assembly, August 20-26, 2007, pp.

[3] Gulotta D., Lucia T., "Conservation of the Built Heritage: Pilot Site Approach to Design a Sustainable Process," Heritage 2, no. 1 (2019): 797-812.
[4] Roland A., Jose I., "Maintenance-Plan-for Heritage-Houses-of-Batanes-Philippines," MUHON: A Journal of Architecture, Landscape Architecture, and the Designed Environment, Issue no. 2, pp. 102-107., 2005, https://journals.upd.edu.ph/index.php/muhon/article/view/ 6304

[5] Ronnie A., "Arkitektura," Egongot Tribe Indigenous Knowledge Systems and Practices Aurora Province. 1 ed., Maria Aurora, Aurora, Philippines, 2017. pp. 1-20. (unpublished)

[6] Rene S. "Heritage Conservation: Applying Scientific Method in Architecture the Lingayen Capitol Building (1918)." MUHON: A Journal of Architecture, Landscape Architecture, and the Designed Environment, Issue no. 3, pp. 28-37., 2009, https://journals.upd.edu.ph/index.php/mu hon/article/view/1317

[7] Sağlar O. "A Framework to Analyze Historic Buildings and Interiors." Structural Studies, Repairs and Maintenance of Heritage Architecture vol. 153, pp. 183-194., 2015. doi:10.2495/STR150161 